\title{
KARAKTERISASI SIFAT FISIS MEMBRAN POLIMER MATRIK KOMPOSIT(PMC) DARI KARBON AKTIF TEMPURUNG KELAPA UNTUK ADSORBSI LOGAM BERAT PADA MINYAK GORENG BEKAS
}

\author{
Oleh: \\ Vivi Nurmayanti ${ }^{1}$ dan Erna Hastuti ${ }^{2}$
}

\begin{abstract}
ABSTRAK: Minyak goreng yang sudah berulangkali dipanaskan akan berwarna hitam dan mengandung logam-logam berat. Untuk meremajakannya diperlukan teknologi alternatif yang mampu mereduksi logam berat pada minyak goreng bekas. Salah satunya adalah membran PMC yang digunakansebagai filter. Membran di uji sifat fisis (debit aliran, kerapatan, porositas) dengan variasi ukuran mesh dan komposisi karbon aktif tempurung kelapa. Matrik berasal dari campuran 0.3 gr PEG, $5 \mathrm{ml}$ PVA, dan $5 \mathrm{ml}$ Aquades. Filler berupa serbuk karbon aktif berasal dari limbah tempurung kelapa. Membran di buat dengan variasi ukuran mesh 60, 100, 120 mesh dan komposisi 1, 3, dan 5 gr. Karbon aktif diperoleh dari tempurung kelapa dengan teknik pemanasan pada temperatur $500^{\circ} \mathrm{C}$ dan aktifasi kimia dengan larutan $\mathrm{H}_{3} \mathrm{PO}_{4} 5$ M. Hasil terbaik ditunjukkan pada membran dengan penambahan karbon aktif 5 gram 120 mesh yang memiliki efektifitas penyaringan paling baik dan adsorbsi logam berat paling maksimal. Debit aliran semakin meningkat dengan nilai $0.0333(\mathrm{ml} / \mathrm{menit})$ dan kerapatan membran semakin kecil $0.95534(\mathrm{gr} / \mathrm{cm})$ dengan porositas $0.39 \%$. Hasil AAS menunjukan logam $\mathrm{Cu}$ mengalami penurunan kadar logam sebesar $0.0819 \mathrm{mg} / \mathrm{L}$ dan logam Fe $0.0285 \mathrm{mg} / \mathrm{L}$. Membran ini merupakan membran mikrofiltrasi dengan rata-rata pori-pori $160.4 \mathrm{~nm}$ yang mampu mereduksi partikel dan bakteri dengan ukuran $400 \mathrm{~nm}$ hingga $2 \mu \mathrm{m}$.
\end{abstract}

Katakunci: Minyak goreng, Karakterisasi, aktifasi, PMC, Membran, karbon aktif, Tempurung Kelapa, Adsorbsi

\begin{abstract}
The used edible oil that has been heated repeatedly turns black and contain heavy metals. to filter it, it is needed alternative technologies that can reduce heavy metals in used edible oil. One of them is PMC membrane technology which used as filter. It's tested physical properties such as (flow rate, density, porosity) by Mesh size variation and the additional of coconut shell activated carbon. Matrix derived from a mixture of $0.3 \mathrm{~g}$ PEG , $5 \mathrm{ml}$ of PVA, and $5 \mathrm{ml}$ distilled . Filler in the form of powder activated carbon derived from coconut shell waste. Membrane is made by mesh size variation 60,100, 120 mesh and the composition of 1, 3, and $5 \mathrm{gr}$. Activated carbon is derived by coconut shell extraction with heating technique (furnace) at a temperature of $500^{\circ} \mathrm{C}$ and a chemical activation with solvent $\mathrm{H}_{3} \mathrm{PO}_{4} 5 \mathrm{M}$. The best filtration indicated by membranes with the addition of 5 grams of activated carbon which has a 120 mesh that has the effectiveness of best filtering used cooking oil and purest heavy metal adsorption. Discharge is being raised with the value of 0.0333 $(\mathrm{ml} / \mathrm{min})$ and density of the membrane smaller $0.95534(\mathrm{~g} / \mathrm{cm})$ with porosity $0.39 \%$. AAS results showed $\mathrm{Cu}$ decreased of metal levels in the mount of $0.0819 \mathrm{mg} / \mathrm{L}$ and $\mathrm{Fe} 0.0285 \mathrm{mg} / \mathrm{L}$. This membrane is a microfiltration membrane with an average of pores $160.4 \mathrm{~nm}$ that was able to reduce the particles and bacteria with size $400 \mathrm{~nm}$ to $2 \mu \mathrm{m}$.
\end{abstract}

Keywords: Edible oil, Characterization, activation, PMC, Actived carbon, membrane, coconut shell, Adsorbsion

\section{PENDAHULUAN}

Minyak merupakan zat makanan yang penting untuk menjaga kesehatan tubuh manusia yang berfungsi sebagai sumber dan pelarut bagi vitamin-vitamin A, D, E dan K,

${ }^{1,2}$ Jurusan Fisika UIN Maulana Malik Ibrahim Malang 
[3] proses penggorengan yang menggunakan energi panas menimbulkan berbagai perubahan yang terjadi pada minyak dan menghasilkan komponen flavor. Perubahan sifat fisiko kimia akibat pemanasan ini mengakibatkan terjadinya kerusakan pada minyak dan menurunkan mutu produk gorengnya. Penurunan kualitas minyak ini berhubungan dengan masalah keamanan produk goreng yang dihasilkan

Pada saat minyak digunakan, akan terjadi perubahan sifat fisiko kimia dari minyak. Perubahan sifat fisik minyak yang terjadi selama pemanasan menyebabkan kenaikan indeks bias, viskositas, warna, dan penurunan titik asap. Viskositas yang meningkat selama pemanasan disebabkan peningkatan komponen hasil degradasi minyak. Komponen nonvolatil yang memiliki berat molekul tinggi hasil reaksi polimerisasi meningkatkan viskositas minyak selama proses penggorengan. Warna minyak yang terbentuk selama proses penggorengan merupakan hasil degradasi warna alami minyak atau komponen bahan pangan yang [2]

Upaya untuk menghasilkan bahan pangan yang berkualitas serta pertimbangan dari segi ekonomi,memacu minat penelitian untuk pemurnian minyak goreng bekas agar minyak dapat dipakai kembali tanpa mengurangi kualitas bahan yang digoreng. Pemurnian minyak goreng bekas merupakan pemisahan produk reaksi degradasi dari minyak. Beberapa cara dapat dilakukan untuk pemurnian minyak goreng bekas, salah satunya adalah pemurnian dengan menggunakan adsorben. Pemurnian minyak goreng bekas dengan adsorben merupakan proses yang sederhana dan efisien [7].

Dalam penelitian ini telah dilakukan penelitian dengan membuat membran dari komposit dengan filler karbon aktif dan matrik polimer. Karbon aktif mampu menyerap logam berat karena mempunyai gugus aktif serta pori-pori yang tersebar pada permukaanya. Oleh karena itu penelitian ini bertujuan untuk mengetahui struktur fisis membran karbon aktif, serta mengetahui konsentrasi adsorpsi logam berat pada minyak goreng bekas dengan membran polimer matrik komposit (PMC)dari karbon aktif tempurung kelapa.

Arang batok kelapa dapat digunakan sebagai kayu bakar biasa atau diolah menjadi arang aktif yang diperlukan oleh berbagai industri pengolahan. Arang aktif merupakan senyawa karbon amorph, yang dapat dihasilkan dari bahan-bahan yang mengandung karbon atau dari arang yang diperlakukan dengan cara khusus untuk mendapatkan permukaan yang lebih luas. Luas permukaan arang aktif berkisar antara 300-3500 $\mathrm{m}^{2}$ /gram dan ini berhubungan dengan struktur pori internal yang menyebabkan arang aktif mempunyai sifat sebagai adsorben. Arang aktif dapat mengadsorpsi gas dan senyawasenyawa kimia tertentu atau sifat adsorpsinya selektif, tergantung pada besar atau volume pori-pori dan luas permukaan. Daya serap arang aktif sangat besar, yaitu 25-100\% terhadap berat arang aktif. Arang aktif adalah bahan berupa karbon bebas atau arang yang telah dibuat dan diolah secara khusus melalui proses aktifasi, sehingga pori-porinya terbuka dan dengan demikian mempunyai daya serap yang besar terhadap zat-zat lainnya, baik dalam fase cair maupun dalam fase gas [4].

Proses aktivasi berlangsung melalui dua tahap yakni proses karbonisasi, dilanjutkan dengan proses aktifasi [5]. Tempurung kelapa sebagai bahan dasarpembuatan karbon aktif, terlebih dahulu dilakukan proses karbonisasi yang dilakukan didalam furnace pada temperatur $500{ }^{\circ} \mathrm{C}$. selama 3 jam [6]. Tahapan kedua yaitu pengaktifan karbon atau 
pengeluaran senyawa yang menutupi rongga dan pori pori arang dapat dilakukan dengan cara dehidrasi menggunakan garam jenuh seperti $\mathrm{MgCl}_{2}, \mathrm{ZnCl}_{2}, \mathrm{CaCl}_{2}$ dll dan asam atau basa $\mathrm{H}_{3} \mathrm{PO}_{4}, \mathrm{H}_{2} \mathrm{SO}_{4}, \mathrm{NaOH}$ dan lain-lain. Penelitian yang dilakukan Tutik M. dan Faizah H [10] menyatakan Semakin tinggi konsentrasi larutan kimia aktifasi maka semakin kuat pengaruh larutan tersebut mengikat senyawa-senyawa tar sisa karbonisasi untuk keluar melewati mikro pori-pori dari karbon sehingga permukaan karbon semakin porous yang mengakibatkan semakin besar daya adsorpsi karbon aktif tersebut. Mekanisme aktifasi arang dengan larutan $\mathrm{H}_{3} \mathrm{PO}_{4}$ bisa dijelaskan dengan gambar 1 .

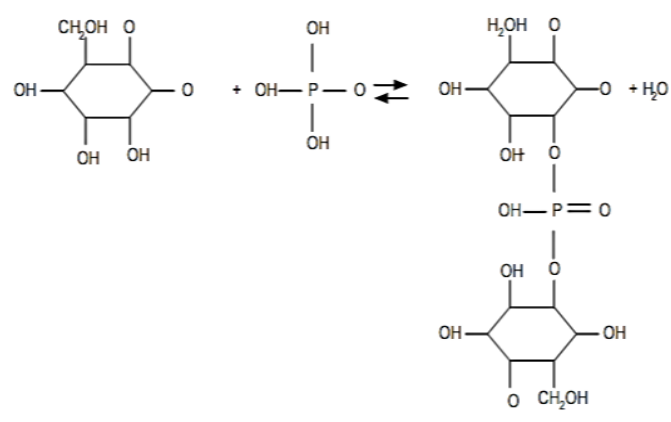

Gambar 1. Mekanisme pengaktifan arang dengan larutan $\mathrm{H}_{3} \mathrm{PO}_{4}[10]$

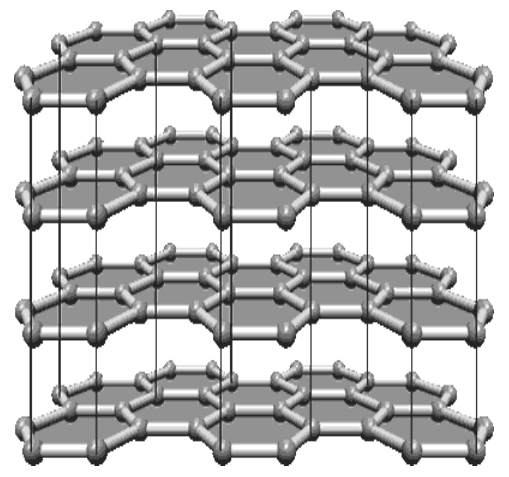

Gambar 2.Struktur grafit karbon aktif [9]

Struktur karbon aktif digambarkan sebagai jaringan yang tumpang tindih karbon dapat menjerap substansi terlarut ke dalam porinya. Ada banyak dari dataran lapisan karbon dengan ikatan silang oleh gugus jembatan alifatik. Hal ini memeberikan suatu sifat yang unik, disebut struktur pori internal yang mudah dipenetrasi. Mikropori merupakan jenis pori yang dianggap penting karena sebagian besar adsorpsi terjadi di dalamnya. Mikropori adalah ruang dua dimensi yang terbentuk dari dua dinding seperti grafit, bidang planar kristalit yang disusun oleh gugus aromatik atom-atom karbon. Banyaknya pori berkorelasi dengan luas permukaan yang meningkatkan kemampuan adsorpsi dari karbon aktif. Mikropori merupakan salah satu kelebihan dari karbon aktif [1]. Struktur grafit dari karbon aktif dapat dilihat pada gambar 2.

Keistimewaan lain dari karbon aktif adalah gugus fungsional pada permukaannya. Gugus kompleks oksigen di permukaan karbon aktif akan membuat permukaan karbon aktif menjadi reaktif secara kimiawi dan menentukan sifat adsorpsinya seperti sifat hidrofilik, keasaman dan potensial negatif. Adsorpsi oleh karbon aktif bersifat fisik, artinya adsorpsi terjadi jika gaya tarik Van der Waals oleh molekul-molekul di permukaan lebih kuat daripada gaya tarik yang menjaga adsorbat tetap berada dalam fluida. Sifat ini menguntungkan karena karbon aktif dapat dipakai ulang melalui proses regenerasi [9]

Membran ialah sebuah penghalang selektif antara dua fasa. Membran memiliki ketebalan yang berbeda-beda, ada yang tebal dan ada juga yang tipis serta ada yang homogen dan yang heterogen. Membran berfungsi memisahkan material berdasarkan ukuran dan bentuk molekul, menahan komponen dari umpan yang mempunyai ukuran lebih besar dari pori-pori membran dan melewatkan komponen yang mempunyai ukuran 
yang lebih kecil. Larutan yang mengandung komponen yang tertahan disebut konsentrat dan larutan yang mengalir disebut permeat.Filtrasi dengan menggunakan membran selain berfungsi sebagai sarana pemisahan juga berfungsi sebagai sarana pemekatan dan pemurnian dari suatu larutan yang dilewatkan pada membran tersebut[3]. Pada penelitian ini teknologi membran yang digunakan adalah membran Polimer matik komposit (PMC), yang menggunakan PVA dan PEG sebagai bahan perekat karbon aktif.

Penelitian ini terdiri dari beberapa tahap, yaitu pembuatan karbon aktif dari tempurung kelapa dan proses pembuatan membran. Tempurung kelapa dibersihkan dari serabutnya, kemudian di cuci dengan aquades agar tidak tercampur dengan kotoran yang lain setelah itu, di keringkan dalam oven pada temperatur $105^{\circ} \mathrm{C}$ untuk menghilangkan kadar airnya. Tempurung kelapa yang telah dikeringkan kemudian diarangkan atau dikarbonisasi dengan furnace tipe 6000 di laboratorium kimia fisika Universitas Islam Negeri Maulana Malik Ibrahim Malang. Proses karbonisasi tempurung kelapa dilakukan dengan pemanasan pada Temperatur $500{ }^{\circ} \mathrm{C}$ selama 3 jam [7] dan dibungkus rapat menggunakan alumunium foil yang bertujuan mencegah masuknya oksigen kedalam sampel. Pada karbonisasi dengan temperatur $170{ }^{\circ} \mathrm{C}$ terjadi proses dehidrasi yang mengguapkan seluruh kandungan air pada tempurung kelapa, $273{ }^{\circ} \mathrm{C}$ terjadi deskomposisi yang mengeluarkan unsur-unsur bukan karbon dalam bentuk gas sedangkan karbonisasi pada temperatur $500{ }^{\circ} \mathrm{C}$ akan menjadi karbon, namun masih ada unsur lain yang masih tertinggal, seperti tar. Proses karbonisasi didapatkan arang tempurung kelapa yang terbentuk adalah sebesar $18 \%$ dari berat awal tempurung kelapa yang dipanaskan didalam furnace. Hal ini menunjukan bahwa hampir seluruh air dan material yang tidak dibutuhkan telah diuapkan pada proses karbonisasi ini. Arang yang di hasilkan didinginkan pada temperature kamar kemudian di haluskan dengan blender dan mortar.

Arang kemudian diaktifasi melalui dua tahap. Tahap pertama adalah aktifasi kimia. Sampel direndam activating agent $\mathrm{H}_{3} \mathrm{PO}_{4} 4 \quad \mathrm{M}$ selama 48 jam [10]. Tujuan aktifasi ini adalah untuk memperluas permukaan pori karbon aktif dan menghalangi pembentukan tar. Semakin tinggi konsentrasi larutan kimia maka makin kuat pengaruh larutan tersebut mengikat senyawa-senyawa tar sisa karbonisasi untuk keluar melewati mikropori dari karbon sehingga permukaan karbon semakin porous dan mengakibatkan semakinbesar daya adsorbs karbon aktif.Arang yang telah direndam kemudian disaring pada kertas saring dan diukur PH residu dari karbon yang telah diaktifasi. Karena activating agent bersifat asam kuat untuk menetralkan $\mathrm{PH}$ karbon aktif, maka karbon aktif ditambahkan $\mathrm{NaOH}$ 3,5 M secara perlahan. Karbon aktif yang telah netral dan teraktifasi dikeringkan pada temperature kamar. Tahap kedua adalah aktifasi fisika. Pada tahap ini sampel dimasukan kembali pada furnace dengan temperatur $500{ }^{\circ} \mathrm{C}$ selama \pm 3 jam untuk menghilangkan kadar tar yang menutupi pori-pori sehingga menghasilkan karbon aktif dengan susunan karbon yang padat berpori. Karbon yang telah teraktifasi kemudian di haluskan dengan mortar kembali karena terjadi pengumpalan pada proses aktifasi tahap pertama. Setelah itu di ayak menggunakan ayakan 60, 100 dan 120 mesh.

Karbon aktif yang telah dihaluskan kemudian digunakan sebagai filler dalam pembuatan membran padat karbon aktif dengan matriksnya adalah campuran dari poli etilen glikol (PEG), poli vinil alkohol (PVA), dan aquades dengan komposisi masingmasing $0.3 \mathrm{gr}, 5 \mathrm{ml}$, dan $5 \mathrm{ml}$. Filler yang dicampurkan pada matriks dibuat dengan variasi 
yaitu 1, 3, 5 gram dan ayakan 60, 100, dan 120 mesh karbon aktif, matrik dan filler dicampur dengan menggunakan magnetic stirrer dengan kecepatan $500 \mathrm{rpm}$ pada temperatur $60{ }^{\circ} \mathrm{C}$ selama 20 menit. Selanjutnya dicetak dalam paralon berdiameter $2 \mathrm{~cm}$ dan dikeringkan dalam temperatur ruangan selama 48 jam, setelah itu di oven selama 2 jam pada temperatur $105{ }^{\circ} \mathrm{C}$ yang bertujuan untuk menghilangkan kadar air yang terjebak didalam membran.

Data yang diperoleh dari uji debit aliran, kerapatan sebelum dan sesudah filtrasi, dan porositas membran karbon aktif dengan variasi ukuran mesh dan komposisi membran. Hasil filtrasi minyak goring bekas di uji menggunakan AAS berupa hasil adsorbsi logam berat $\mathrm{Fe}$ dan $\mathrm{Cu}$ kemudian membran dengan komposisi terbaik di uji menggunakan Scanning Electron Microscop (SEM) yang berupafoto, kemudian dikorelasikan dengan besar adsorbsi logam berat pada minyak goreng bekas.

di jelaskan pada kajian teori bahwa :

Debit aliran $(\mathrm{Q})=\frac{v(m l)}{t(\text { menit })}$
Kerapatan $(\rho)=\frac{m(g r)}{v(m l)}$
Porositas $(\mathrm{P})=\frac{M b-M k}{V(\text { benda })} \times \frac{1}{\rho(\text { air })} \times 100 \%$

Keterangan :

$$
\begin{aligned}
& >\rho=\text { kerapatan }\left(\mathrm{gr} / \mathrm{cm}^{3}\right) \\
& >\mathrm{m}=\text { massa membran }(\mathrm{gram}) \\
& >\mathrm{v}=\text { volume membran }\left(\mathrm{cm}^{3}\right) \\
& >\mathrm{Q}=\text { debit aliran }(\mathrm{ml} / \mathrm{menit}) \\
& >\mathrm{t}=\text { waktu yang dibutuhkan untuk filtrasi (menit) } \\
& >\mathrm{Mb}=\text { massa basah }(\mathrm{gr}) ; \mathrm{Mk}=\text { massa kering }(\mathrm{gr}) \\
& >\rho(\text { air })=\text { densitas air } 1\left(\mathrm{gr} / \mathrm{cm}^{3}\right)
\end{aligned}
$$

\section{HASIL DAN PEMBAHASAN}

Pembuatan membran dilakukan dengan metode polimer matrik komposit (PMC). Keunggulan metode ini memiliki kekuatan dan kekakuan yang baik, dengan penambahan filler akan memperbaiki sifat-sifat membran, yang diharapkan mempunyai kekuatan yang baik dan berpori. Pori-pori membran dibuat dengan ukuran yang sangat kecil, sehingga dimungkinkan mampu mengadsorbsi logam berat pada minyak goreng bekas oleh membran karbon aktif. Pengaktifasian fisika maupun kimia diperlukan untuk mengaktifasi karbon pada tempurung kelapa serta proses homogenisasi antara matrik dan filler, agar mendapatkan komposisi yang baik dan campuran yang merata.

Pengujian hasil penyaringan debit aliran dan kerapatan membrane menunjukan bahwa membran yang telah dibuat mampu mereduksi kation pada logam $\mathrm{Fe}$ dan $\mathrm{Cu}$. 


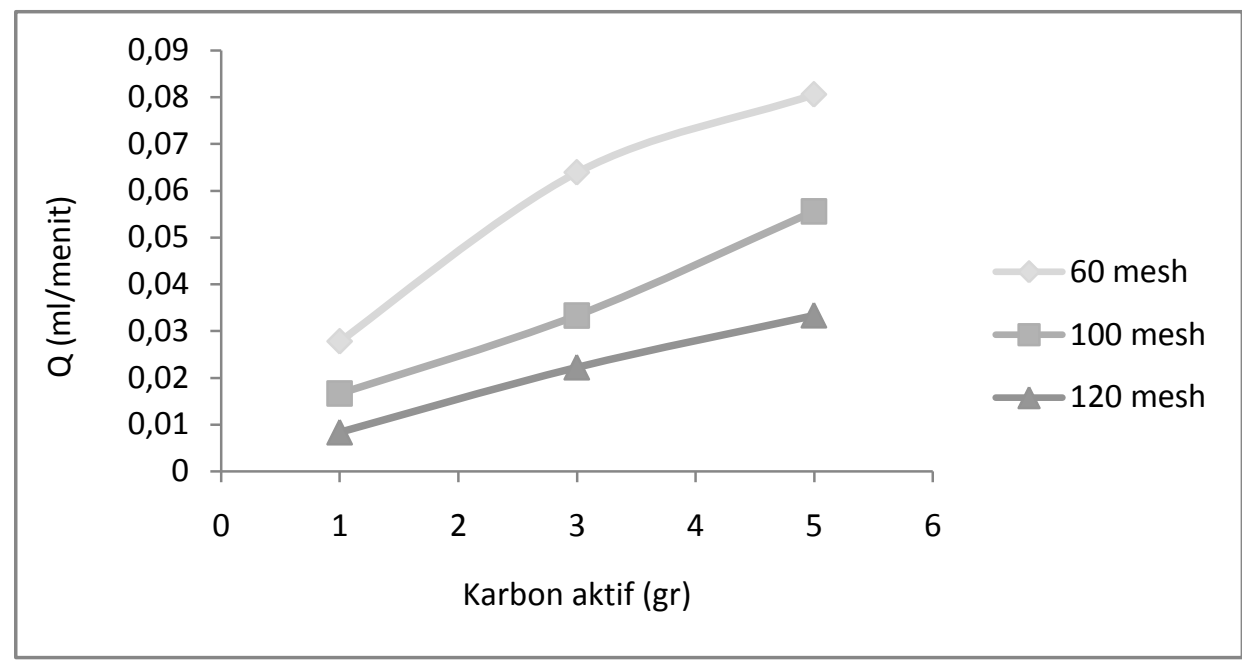

Gambar 3. Grafik pengaruh variasi mesh dan penambahan karbon aktif pada debit aliran

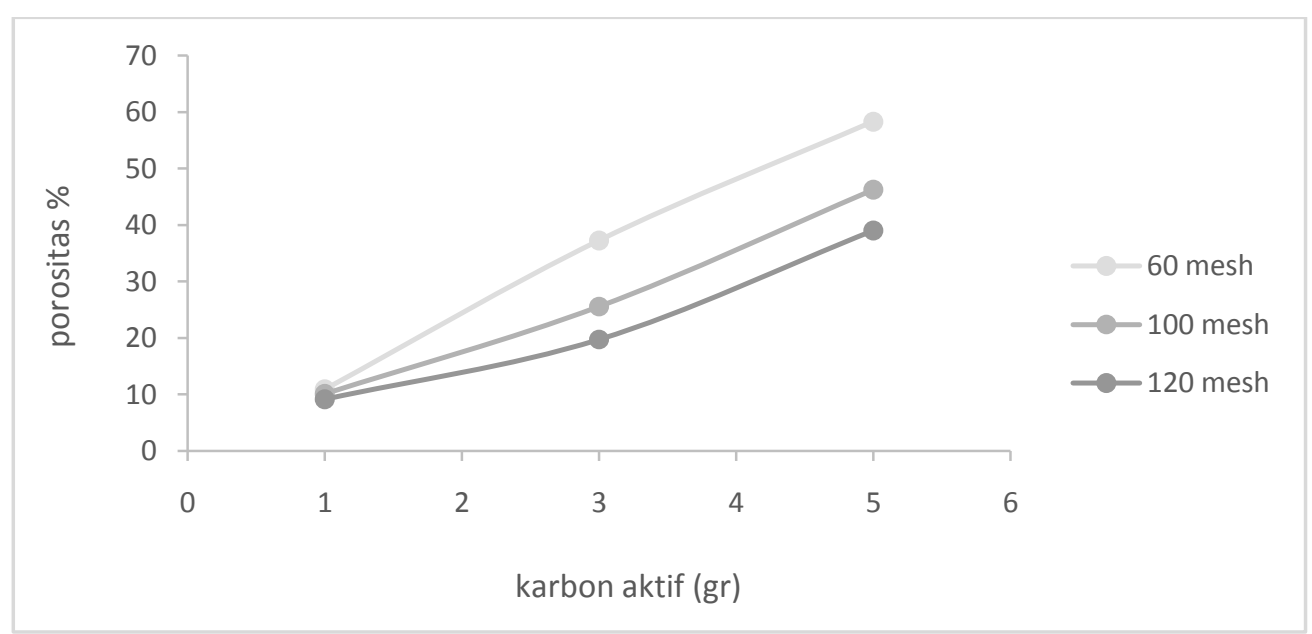

Gambar 4. Grafik pengaruh variasi mesh dan penambahan karbonaktif pada porositas membran

Gambar 3 menunjukan, penambahan karbon dapat meningkatkan kualitas penyaringannya, karena komposisi dari matrik dan filter membran yang berimbang sehingga sebaran pori semakin memerata. Terlihat dari data yang diperoleh dengan penambahan karbon aktif 5 gram debit aliran semakin meningkat.Ukuran mesh juga mempengaruhi kualitas penyaringannya. Dalam massa yang sama, 120 mesh mempunyai luas permukaan sentuhan lebih besar dari 60 mesh, sehingga debit alirannya menurun. Debit aliran dipengaruhi oleh luas permukaan sentuhan butir karbon aktif. Semakin kecil mesh karbon aktif makin besar jumlah luas permukaan sentuhannya, dan makin padat kerapatan membrannya. Debit aliran paling maksimuma dalah pada penambahan 5 gram karbon aktif 60 mesh yaitu $0.8056 \mathrm{~cm}^{3} / \mathrm{s}$ dan kerapatannya $0.889 \mathrm{gr} / \mathrm{cm}^{3}$.

Ukuran mesh mengindikasikan kasar dan halusnya tekstur karbon aktif. Dari pengujian porositas membran (gambar 4) menunjukan tekstur membran yang kasar membuat aliran minyak mudah melewati membran dan meloloskan kotoran yang masih tersisa pada minyak goreng bekas, sebaliknya pada membran yang bertekstur lebih halus, 
memiliki pori-pori kecil. Data hasil menunjukan bahwa semakin halus ukuran karbon aktif kapasitas minyak yang mengalir melalui membran semakin berkurang dan meningkat kemampuan membran untuk mengadsorbsi kotoran pada minyak goreng bekas yang berupa logam $\mathrm{Fe}$ dan $\mathrm{Cu}$. Hasil AAS pada minyak goreng hasil penyaringan membran karbon aktif ditunjukan pada tabel 1.

Tabel 1. Kadar logam berat Fedan $\mathrm{Cu}$

\begin{tabular}{cccccc}
\hline \multirow{2}{*}{$\begin{array}{c}\text { Ukuran } \\
\text { mesh }\end{array}$} & $\begin{array}{c}\text { Karbon } \\
\text { aktif }(\mathrm{gr})\end{array}$ & \multicolumn{2}{c}{$\begin{array}{c}\text { Kadar logam sebelum } \\
\text { filtrasi } \mathrm{mg} / \mathrm{L}\end{array}$} & \multicolumn{2}{c}{$\begin{array}{c}\text { Kadar logam setelah } \\
\text { filtrasi } \mathrm{mg} / \mathrm{L}\end{array}$} \\
\cline { 2 - 5 } & & $\mathrm{Fe}$ & $\mathrm{Cu}$ & $\mathrm{Fe}$ & $\mathrm{Cu}$ \\
\hline \multirow{2}{*}{60} & 1 & & 0.0378 & 0.0029 \\
& 3 & & 0.0206 & 0.0027 \\
& 5 & & 0.0161 & 0.0019 \\
& 1 & & & 0.0121 & 0.0007 \\
100 & 3 & \multirow{2}{*}{0.041} & 0.0082 & 0.0203 & 0.0009 \\
& 5 & & & 0.0126 & 0.0002 \\
& 1 & & & 0.0209 & 0.0005 \\
& 3 & & & 0.0169 & 0.0005 \\
& 5 & & & 0.0125 & 0.0002 \\
\hline
\end{tabular}

Efisiensi komposisi dan kualitas membran yang paling baik adalah penambahan 5 gram karbon aktif pada 120 mesh yang mampu menurunkan kosentrasi Fe dari 0.041 menjadi 0.0125 dan $\mathrm{Cu}$ dari 0.0082 menjadi 0.0002. Data kerapatan sebelum dan sesudah penyaringan mengalami kenaikan yang mengindikasikan adanya kotoran yang terperangkap di dalam membran.

Tabel 1. menunjukan bahwa membran karbon aktif tempurung kelapa lebih efektif menyerap logam $\mathrm{Cu}$ dari pada logam Fe. Dimungkinkan Karena ukuran jari-jari Fe lebih kecil dari pada $\mathrm{Cu}$. Penurunan kadar logam dapat dilihat secara fisik dari sampel hasil uji. Perubahan warna pada sampel sebelum dan sesudah penyaringan, terlihat pada gambar 5 .

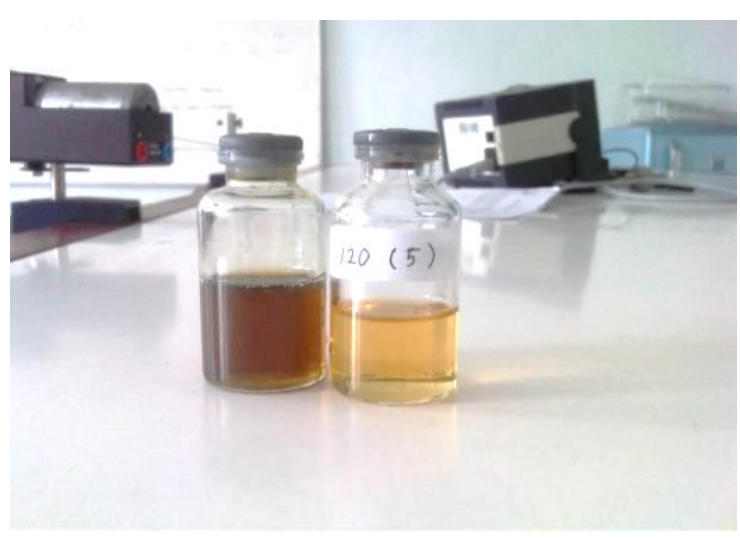

Gambar5.Minyak sebelum dan sesudah penyaringan

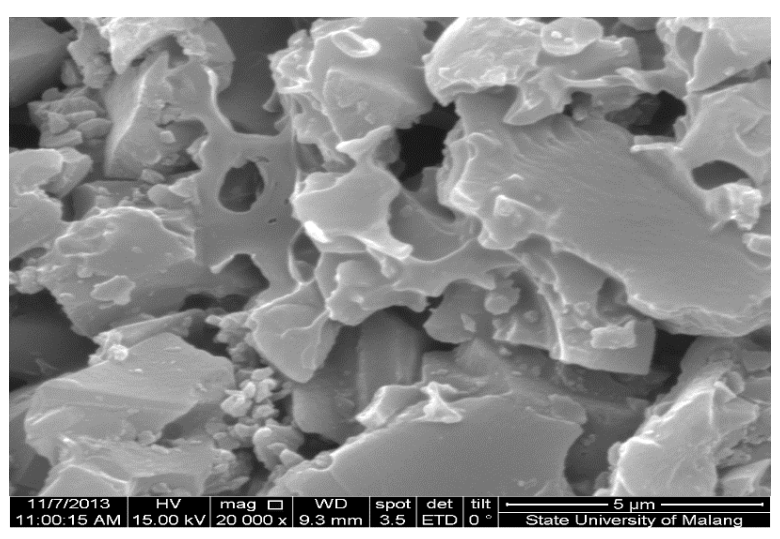

Gambar 6. Hasil SEM membrane dengan penambahan 5 gram 120 mesh

Hasil terbaik penyerapan karbon aktif kemudian dikarakterisasi struktur mikronya dengan SEM. Hasil foto scanning SEM gambar 4 pada membran dengan penambahan 
karbon aktif 5 gram 120 mesh, menunjukan rata-rata ukuran pori sebesar $160 \mathrm{~nm}$. Pada range ini membran mampu memfiltrasi jamur, bakteri dan dapat digunakan sebagai DPF dust removal filter [5]

Membran yang telah dibuat dari karbon aktif tempurung kelapa mempunyai keunggulan untuk mengurangi kadar $\mathrm{Fe}$ dan $\mathrm{Cu}$. Arang aktif dari tempurung kelapa merupakan senyawa karbon amorph, yang mengandung karbon. Luas permukaan arang aktif berkisar antara 300-3500 m²/gram dan ini berhubungan dengan struktur pori internal yang menyebabkan arang aktif mempunyai sifat sebagai adsorben. Arang aktif dapat mengadsorpsi gas dan senyawa-senyawa kimia tertentu atau sifat adsorpsinya selektif, tergantung pada besar atau volume pori-pori dan luas permukaan. Daya serap arang aktif sangat besar, yaitu 25-100\% terhadap berat arang aktif. Pori-pori yang terbukadanmenyebarpadapermukaankarbonaktifmelaluihasilpengaktifasianyamembuat daya serap yang besar terhadap zat-zat lainnya, baik dalam fase cair maupun dalam fase gas [4].

Minyak goreng bekas yang mengandung logam $\mathrm{Fe}$ dan $\mathrm{Cu}$ dialirkan melewati karbon aktif. Logam $\mathrm{Cu}$ dan $\mathrm{Fe}$ terikat pada membran karbon aktif dan sebagian logam $\mathrm{Cu}$ dan $\mathrm{Fe}$ masih bisa meloloskan diri dari permukaan karbon aktif. Proses Adsorbsi logam $\mathrm{Cu}$ dan $\mathrm{Fe}$ oleh karbon aktif dikarenakan adanya perbedaan energi potensial antara permukaan karbon aktif tempurung kelapa dalam minyak, baik itu melibatkan gaya fisika maupun kimia. Adsorsi fisika melibatkan gaya antarmolekul (gaya Van Der Walls). Gaya Van Der Walls terjadi akibat interaksi antara molekul-molekul non polar (Karbon aktif) dengan molekul polar yang berupa pengotor (gaya dipol-dipol terinduksi).

Secara kimia membran karbon aktif mengendapkan kation $\mathrm{Fe}$ dan $\mathrm{Cu}$. Interaksi yang terjadi adalah interaksi intermolekuler sehingga logam mampu tertahan pada permukaan membran. Molekul adsorben secara kimiawi dianggap mempunyai sisi aktif atau gugus fungsional yang mampu berinteraksi denganlogam. Seperti dalam ilustrasi struktur carboxlic yang terdapat dalam karbon aktif. Pada gambar 7.

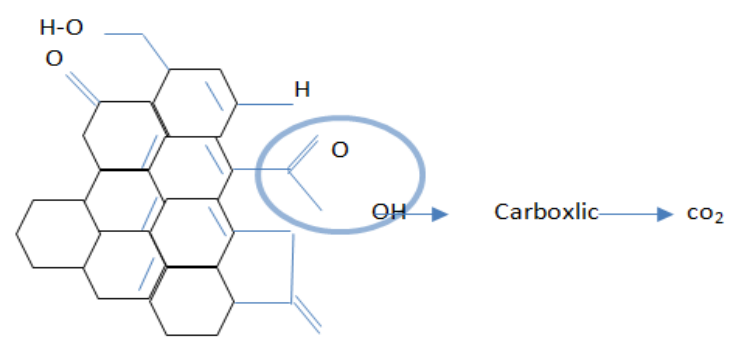

Gambar 7. Struktur carbolic karbon aktif
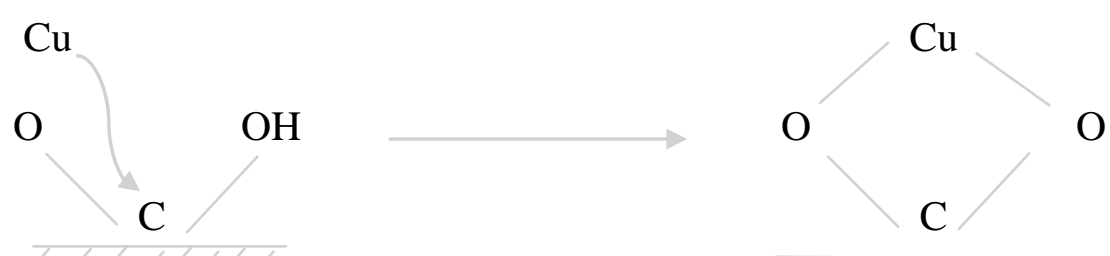

Gambar 8. Mekanisme pertukaran Kation pada carboxlic gruo 


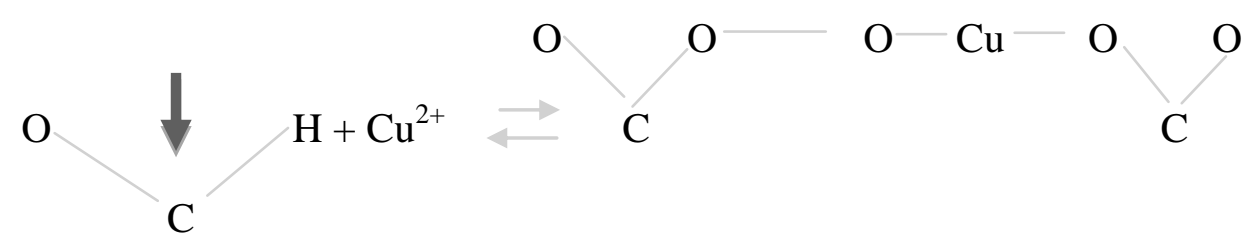

Gambar 9. Pembentukan ion antara ion logam $\mathrm{Cu}$ dengan karbon aktif

$$
\begin{aligned}
& \mathrm{C}-\mathrm{OH}+\mathrm{Cu}^{+} \rightleftarrows \mathrm{CO}-\mathrm{Cu}+\mathrm{H}^{+} \\
& \mathrm{C}-\mathrm{OH}+\mathrm{Cu}^{2+} \rightleftarrows \mathrm{CO}-\mathrm{Cu}-\mathrm{CO}
\end{aligned}
$$

Gambar 10. Gugus $\mathrm{OH}$ yang terikat pada permukaan dengan ion logam yang bermuatan positif

Interaksi antara $\mathrm{OH}$ dengan ion logam melalui mekanisme pertukaran ion, karena atom oksigen pada gugus $\mathrm{OH}$ mempunyai 2 elektron bebas. Sedangkan ion logamnya memiliki orbital d kosong. Orbital d ini yang akan di isi elektron bebas dari atom oksigen pada gugus $\mathrm{OH}^{-}$.Membran karbon aktif tempurung kelapa secara fisika maupun kimia dapat mengadsorsi logam berat pada minyak goreng bekas. Struktur karbon aktif yang mempunyai pori-pori yang saling berhubungan, sehingga mempunyai daya serap lebih besar dari pada karbon yang belum teraktifasi.

\section{KESIMPULAN}

Berdasarkan hasil penelitian dan pembahasan yang telah diuraikan, dapat diambil kesimpulan sebagai berikut:

1. Hasil penelitian pengaruh ukuran filler dan komposisi membran karbon aktif tempurung kelapa pada membran polimer matrix composite (PMC) sebagai adsorbsi logam berat pada minyak goreng bekas menunjukkan dalam massa yang sama, 120 mesh mempunyai luas permukaan sentuhan lebih besar dari 60 mesh, sehingga debit alirannya menurun dan kerapatan yang semakin menurun. Kerapatan yang besarmenghasilkanporositas yang kecil sehingga membran dengan komposisi 5 gram pada 120 mesh berkecenderungan memfiltrasi kotoran minyak goreng bekas yang lebih banyak.

2. Hasil AAS menunjukan adanya kecendrungan membrankarbonaktif dalam menurunkankadarlogamberat $\mathrm{Fe}$ dan $\mathrm{Cu}$. Komposisi paling baik adalah dengan penambahan 5 gram karbon aktif 120 mesh yang menurunkan kadar logam berat $\mathrm{Fe}$ sampai $85 \%$ yaitu $0.0125 \mathrm{mg} / \mathrm{L}$ dan kadar logam berat $\mathrm{Cu}$ sampai $95 \%$ yaitu 0.0002 $\mathrm{mg} / \mathrm{L} . M e m b r a n$ ini merupakan membran mikrofiltrasi dengan rata-rata pori-pori adalah $160 \mathrm{~nm}$ yang berpotensi mereduksi partikel ragi, jamur dan bakteri dengan ukuran 400 nm hingga $2 \mu \mathrm{m}$ 


\section{DAFTAR PUSTAKA}

[1] Agustina, Siti dkk. 2006. Penggunaan Teknologi Membran Pada Pengolahan Air Limbah Industri Kelapa Sawit: Jurnal Penelitian pdf.

[2] Akoh dan D.B. Min (ed). 2002. Food Lipids 2nd Edition. Marcel Dekker. Inc. New York

[3] Blumenthal, M.M. 1996. Frying Technology, Bogor:Institute Pertanian Bogor.

[4] Hambali, Erliza dkk. 2010.Tempurung Kelapa Bahan Baku Biobriket yang prospektif di Indonesia. Fakults Teknologi IndustriInstitut Teknologi Bandung: Jurnal penelitian $p d f$

[5] Iwamoto, Yuji. dan Kawamoto, Hiroshi. 2009. Trends in Research and Development of Nanoporous Ceramic Separation Membranes. Science \& Technology quarterly review no. 32. Jurnal penelitian pdf.

[6] Joni Tallo Lembang, dkk. 1995. Rekayasa Pembuatan Tungku Pembakaran Sekam padi untuk pembuatan Arang Aktif dari Sekam Padi. Ujung Pandang: Balai Penelitian dan Pengembangan Industri

[7] Marsh, dkk. 2006. Actived Carbon. LondonUK: Elviser Ltd. Journal International pdf

[8] Pujiyanto. 2010. Pembuatan Karbon Aktif Dari Tempurung Kelapa Dan Batu Bara. Fakultas Teknik Universitas Indonesia. Jurnal Penelitian Pdf

[9] Roop Chand, and Goyal, Meenakshi, 2005.Activated Carbon Adsorption. New York: Taylor and Francis Group

[10] Tutik M danFaizah H, 2001. Aktifasi Arang Tempurung Kelapa Secara Kimia dengan Larutan Kimia $\mathrm{ZnCl2,} \mathrm{KCl}$ dan HNO3. Jurusan Teknik Kimia UPN. Yogyakarta. 